\title{
Intrasellar Clear Cell Meningioma Mimicking Invasive Pituitary Adenoma: A Case Report and Review of the Literature
}

\author{
Invaziv Hipofiz Adenomunu Taklit Eden Intrasellar Berrak Hücreli \\ Menenjiyoma: Olgu Sunumu ve Literatürün Gözden Geçirilmesi
}

\author{
Senlin YIN, Peizhi ZHOU, Qiang LI, Shu JIANG \\ West China Hospital, Department of Neurosurgery, Chengdu, Sichuan, China
}

Corresponding Author: Shu JIANG / E-mail: jiangshuwch@hotmail.com

\begin{abstract}
The authors report on a 55-year-old man with complaints of intermittent pulsatile headache for 6 months, vision loss of the right eye and diplopia for 2 months. A magnetic resonance image (MRI) showed a large heterogeneously enhanced intrasellar mass lesion, occupying the entire hypophyseal fossa and extending into the sphenoid sinus. The patient underwent microscopic transsphenoidal surgery for removal of the tumor. Microscopic examination with hematoxylin\&eosin and immunohistochemical staining of the tumor specimen was performed and confirmed the diagnosis of clear cell meningioma (CCM). Though postoperative MRI indicated gross total resection of the tumor, rapid recurrence was detected at 4 months after surgery. Gamma knife radiotherapy was administered. To the authors' knowledge, the present case is the first case of transsphenoidal removal of CCM. We reviewed the current literature on this rare histological type of meningioma in the sellar region.
\end{abstract}

KEYWORDS: Clear cell meningioma, Pituitary adenoma, Differential diagnosis

öz

Yazarlar 6 aydan beri intermitan pulsatil baş ağrısı, 2 aydan beri sağ gözde görme kaybı ve diplopi şikayeti olan 55 yaşında bir erkek hastayı sunuyorlar. Manyetik rezonans görüntüleme (MRG); tüm hipofizeal fossayı dolduran, sfenoid sinüse doğru yayılan, büyük, heterojen olarak kontrast tutan intrasellar kitle lezyonunu ortaya koydu. Hastaya tümör rezeksiyonu amacıyla mikroskopik transsfenoidal cerrahi uygulandı. Tümör dokusunun hematoksilen \& eozin ve immünohistokimyasal boyalarla yapılan mikroskopik incelemesi yapıldı ve berrak hücreli menenjiyoma (BHM) tanısı konuldu. Postoperatif MRG tümörün gros total olarak çıkartıldığını gösterdi, ancak cerrahiden 4 ay sonra hızlı nüks gözlendi. Hastaya gamma knife radyocerrahisi uygulandı. Yazarların bilgisine göre bu olgu transsfenoidal rezeksiyon uygulanan ilk BHM olgusudur. Sellar bölgedeki bu nadir menenjiyoma histolojik tipi ile ilgili mevcut literatürü taradık.

ANAHTAR SÖZCÜKLER: Berrak hücreli menenjiyoma, Hipofiz adenoma, Ayırıcı tanı

\section{INTRODUCTION}

Clear cell meningioma (CCM) is a rare histological variant of World Health Organization (WHO) grade II meningiomas (6), constituting only $0.2 \%$ of all intracranial meningiomas. According to previous reports, CCMs most frequently occur at the spinal dura or cerebellopontine angle, with female predominance. Curiously, CCMs at the sellar region are extremely rare and no intrasellar CCM has been reported.

\section{CASE REPORT}

A 55-year-old male was admitted with complaints of intermittent pulsatile headache for 6 months, vision loss of the right eye and diplopia for 2 months. Physical examination revealed decreased visual acuity and hemianopia of both eyes. Light reflex and movement of both eyes were intact.

An enhanced MRI was performed, depicting a large intrasellar mass lesion $(4.0 \times 2.8 \times 2.0 \mathrm{~cm})$ that was heterogenously contrast-enhanced, occupying the entire hypophyseal fossa and extending into the sphenoid sinus, with significant displacement of the pituitary gland and the optic chiasm. Enhancement of adjacent dura mater was not found (Figure 1A). Though compression of the pituitary gland was confirmed, the laboratory tests revealed no hormone disturbance.

Preoperative MRI images indicated that the dorsum sellae had been invaded and the sphenoid sinus was occupied by tumor. Therefore, we performed a microscopic transsphenoidal surgery to remove the tumor. The tumor was soft and moderately vascularized, with irregular destruction of surrounding bone. Gross total resection was achieved.

Microscopic examination of the tumor specimen was performed. With hematoxylin and eosin (H\&E) staining, the tumor cells were typically polygonal in shape and the cytoplasm was rich in glycogen, with round-to-oval nuclei. Prominent interstitial collagen was also noted. Immunohistochemical stain- 
ing was positive for pancytokeratin (PCK), epithelial membranous antigen (EMA), and neuron-specific enolase (NSE), s-100. Positive nuclear staining for progesterone receptors (PR) was found (Figure 2A-F). Ki-67 was positive in approximately $2 \%$ of the tumor cells. Meanwhile, staining was negative for glial fibrillary acidic protein (GFAP), renal cell carcinoma (RCC) marker, CK5/6/7, P63, parathyroid hormone (PTH), thyroid transcription factor 1 (TTF-1) and epidermal growth factor receptor (EGFR). Enhanced abdominal CT was negative for the existence of primary tumors such as RCC. These findings were in line with the $\mathrm{WHO}$ definition of clear cell meningiomas. No serious complications were found postoperatively. The patient was discharged one-week after surgery. At discharge, the visual acuity as well as the visual field of the patient had partially recovered and MRI found no residual tumor or recurrence (Figure 1B). However, local recurrence was found at the 4-month follow-up (Figure 1C), without prominent visual deterioration or pituitary dysfunction. Radiotherapy was therefore suggested. We performed Leksell gamma knife radiosurgery with $15 \mathrm{~Gy}$ of irradiation.

\section{DISCUSSION}

Clear cell meningiomas have been recognized as a unique variant of Grade I meningioma in the WHO classification in 1993 (5) due to their bland histological appearance. As evidence of a high recurrence rate and aggressive biological behavior accumulates, CCMs are now classified as an infrequent variant of Grade II meningiomas.

CCMs are most frequently found at the cerebellopontine angle or in the spinal cord, especially the cauda equina. CCMs within the sellar region were especially rare, with only five cases reported $(1,2,4,8,10)$ (Table I), which exhibited several distinctions from other CCMs. Although CCMs were predominantly reported in female patients, CCMs within the sellar region were mostly male cases. Reviews indicated that CCMs cases were mostly young patients. In contrast, the sellar CCM cases tended to be older, with mean age of 49 years. Due to the unique anatomic location, distinctive clinical symptoms such as disturbance of cranial nerves II and III was common, as observed in four cases.

Comparing to the five cases of sellar CCMs, our case was unique in several ways:

1) The tumor was located in the hypophyseal fossa, invaded the sellar floor and occupied the sphenoid sinus.

2) No clear boundary was seen between the tumor and the pituitary gland.

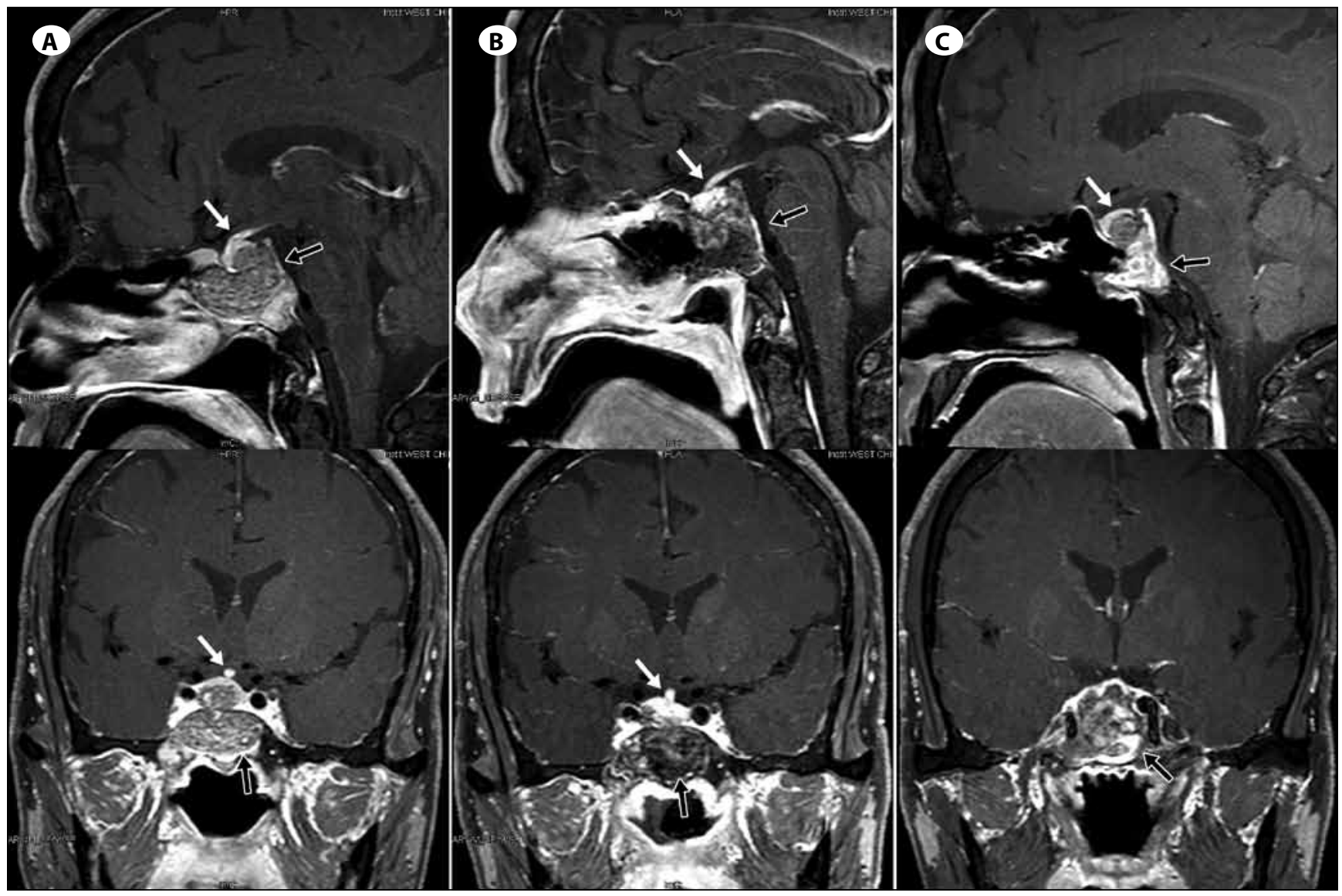

Figure 1: Gadolinium-Enhanced T1-weighted MRI images of the patient (upper - sagittal scan, lower - coronal scan, the white arrow indicates pituitary). A) Preoperative images. The black arrows indicate the tumor; B) Postoperative day-7 images. The black arrows indicate the hemostasis material. C) 4-month follow-up images. The black arrows indicate the recurrent tumor. 
3) Gross total resection was achieved through the transsphenoidal approach.

4) Rapid local recurrence occurred in three months.

The radiological appearance of our case is especially interesting in two aspects: absence of the dural tail sign as well as the border between the tumor and the pituitary gland. A typical meningioma has iconic dural enhancement on MRI around the tumor, known as the dural tail sign. The presence of the dural tail sign was also noted in CCMs of other origins (4), while it could rarely be absent $(3,7)$. The dural tail sign was seen in all previous cases of CCMs within the sellar region $(1,2,4,8,10)$ but it was absent in our case. Therefore, the absence of the dural tail sign cannot deny the possibility of a CCM, especially for masses within the sellar region. Besides, the tumor protruded upwards instead of evenly compressing the adjacent structure like other sellar meningiomas, mimicking an invasive pituitary adenoma that originated from the

Table I: Literature Review of Cases of Clear Cell Meningiomas within the Sellar Region

\begin{tabular}{|c|c|c|c|c|c|c|}
\hline Author & Year & $\begin{array}{l}\text { Age/ } \\
\text { Gender }\end{array}$ & Location & Clinical features & Resection & Recurrence \\
\hline Chen & 2011 & $M / 63$ & Left tuberculum sellae & Vision loss & GTR & 96 months \\
\hline Prayson & 2010 & $M / 79$ & Right clinoidal & N/A & STR & $\mathrm{N}$ at 11 months \\
\hline Ohba & 2010 & $M / 60$ & Right posterior clinoid & Diplopia and right ptosis & STR & $\mathrm{N}$ at 3 months \\
\hline Baxter & 2009 & $F / 32$ & Tuberculum sellae & $\begin{array}{c}\text { Vision deterioration and left } \\
\text { hemianopia }\end{array}$ & STR & $\mathrm{N}$ at 7 months \\
\hline Jain & 2007 & $M / 11$ & Left parasellar & $\begin{array}{c}\text { Ptosis, recurrent headache, } \\
\text { hemiparesis }\end{array}$ & GTR & $\mathrm{N}$ at 84 months \\
\hline
\end{tabular}

M: male, F: female, N/A: not Available, GTR: gross total resection, STR: subtotal resection, N: no recurrence.

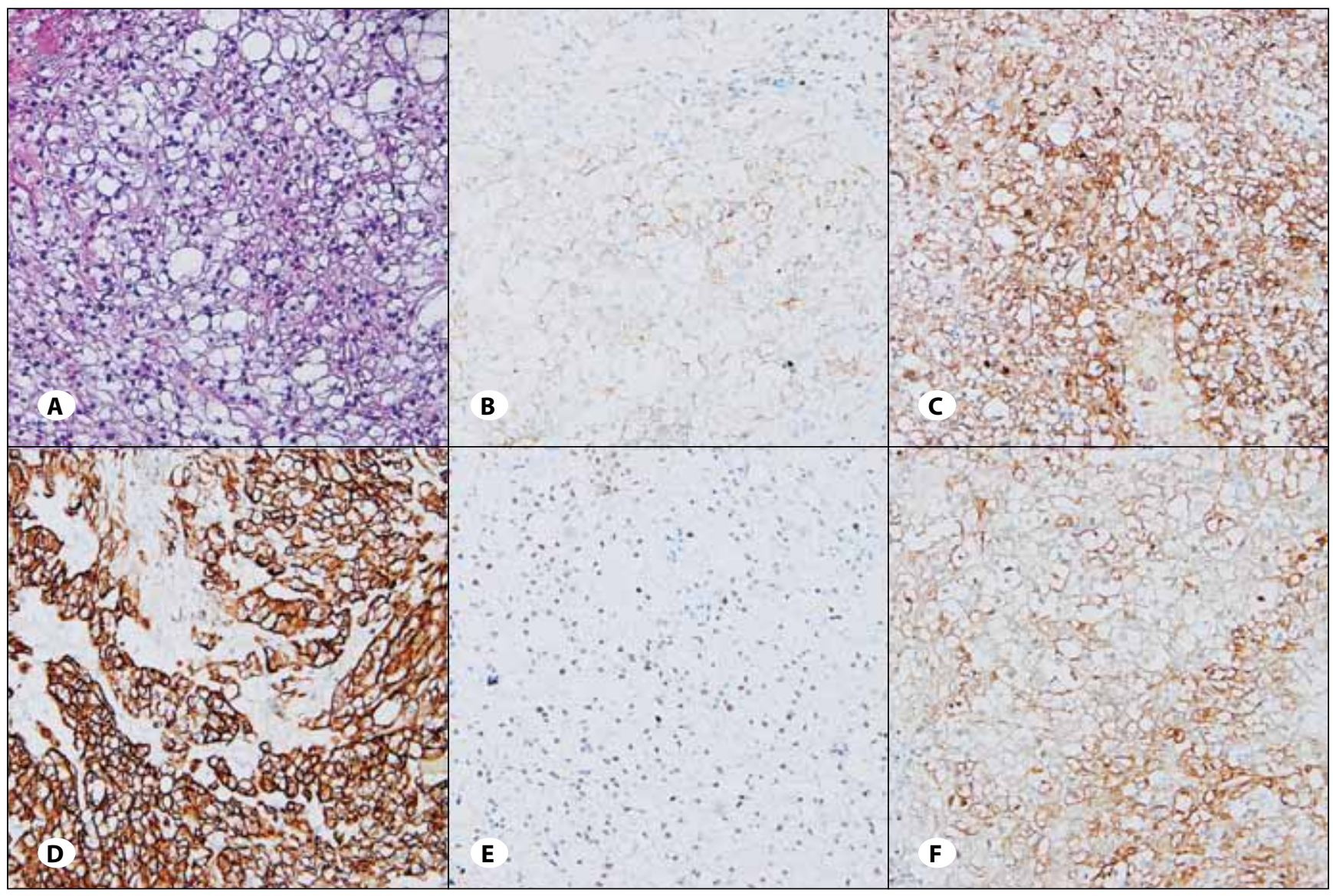

Figure 2: Photomicrographs showing clusters of polygonal tumor cells with glycogen-rich cytoplasm. Immunohistochemical staining is positive for EMA (B), NSE (C), PCK (D), PR (E), S-100 (F). (A. hematoxylin and eosin stain at 200x, B-F immunohistochemical staining photomicrographs at 200x). 
lower part of the pituitary gland. Such peculiar radiological appearance posed a challenge for both the neurosurgeons and radiologist in determining the precise diagnosis of the patient.

In terms of prognosis, a review of atypical meningiomas (9) suggested that the overall five-year recurrence rate $(41 \%)$ was higher than benign meningiomas (12\%). Curiously, previous reports of sellar CCMs showed a low recurrence rate (1 in 5 cases, at 84 months postoperatively). In contrast, we observed early recurrence within 4 months after surgery. We therefore propose that the recurrence rate for sellar CCMs might not be as low as previously assumed, and that surgery alone is not enough. Adjuvant radiotherapy and chemotherapy may be an effective supplement postoperatively.

Clear cell meningiomas are an infrequent histological variant of atypical (WHO Grade II) meningiomas. CCMs within the sellar region were extremely rare, with no previous reports of CCM in the hypophyseal fossa and sphenoid sinus. We suggest total removal through a less invasive transsphenoidal approach for sellar CCMs, with adjuvant radiotherapy to prevent early recurrence. Close follow-up is crucial, due to possibility of rapid recurrence and deterioration.

\section{REFERENCES}

1. Baxter DS, Smith P, Stewart K, Murphy M: Clear cell meningioma presenting as rapidly deteriorating visual field and acuity during pregnancy. J Clin Neurosci 16:1502-1504, 2009

2. Chen H, Li XM, Chen YC, Wu JS, Dou YF, Wang Y, Xu J, Zhong P, Jiang CC, Wang XQ: Intracranial clear cell meningioma: A clinicopathologic study of 15 cases. Acta Neurochir (Wien) 153:1769-1780, 2011
3. Holtzman RN, Jormark SC: Nondural-based lumbar clear cell meningioma: Case report. J Neurosurg 84:264-266, 1996

4. Jain D, Sharma MC, Sarkar C, Suri V, Garg A, Singh M, Sharma BS, Mahapatra AK: Clear cell meningioma, an uncommon variant of meningioma: A clinicopathologic study of nine cases. J Neurooncol 81:315-321, 2007

5. Kleihues $\mathrm{P}$, Burger $\mathrm{P}$, Scheithauer B: Histological typing of tumors of the central nervous system: World Health Organization international classification of tumors. Berlin: Springer, 1993

6. Louis DN, Ohgaki H, Wiestler OD, Cavenee WK, Burger PC, Jouvet A, Scheithauer BW, Kleihues P: The 2007 WHO classification of tumours of the central nervous system. Acta neuropathol 114:97-109, 2007

7. Miranda P, Simal JA, Vila M, Hernandez M, Menor F, AlvarezGarijo JA: Posterior fossa clear cell meningioma without dural attachment in a child. Childs Nerv Syst 25:389-392, 2009

8. Ohba S, Sasaki H, Kimura T, Ikeda E, Kawase T: Clear cell meningiomas: Three case reports with genetic characterization and review of the literature. Neurosurgery 67:E870-871; discussion E871, 2010

9. Perry A, Stafford SL, Scheithauer BW, Suman VJ, Lohse CM: Meningioma grading: An analysis of histologic parameters. Am J Surg Pathol 21:1455-1465, 1997

10. Prayson RA, Chamberlain WA, Angelov L: Clear cell meningioma: A clinicopathologic study of 18 tumors and examination of the use of CD10, CA9, and RCC antibodies to distinguish between clear cell meningioma and metastatic clear cell renal cell carcinoma. Appl Immunohistochem Mol Morphol 18:422-428, 2010 